OPEN ACCESS

Citation: Wong Sin Yeng et al. (2020) Studies on Homalomeneae (Araceae) of Sumatera VI: Two remarkable new species of Homalomena [Chamaecladon Clade]. Webbia. Journal of Plant Taxonomy and Geography 75(1): 117-122. doi: 10.36253/jopt-7947

Received: January 29, 2020

Accepted: March 23, 2020

Published: June 30, 2020

Copyright: (c) 2020 Wong Sin Yeng, Peter C. Boyce, Alistair Hay. This is an open access, peer-reviewed article published by Firenze University Press (http://www.fupress.com/webbia) and distributed under the terms of the Creative Commons Attribution License, which permits unrestricted use, distribution, and reproduction in any medium, provided the original author and source are credited.

Data Availability Statement: All relevant data are within the paper and its Supporting Information files.

Competing Interests: The Author(s) declare(s) no conflict of interest.

Editor: Thomas B. Croat

\section{Studies on Homalomeneae (Araceae) of Sumatera VI: Two remarkable new species of Homalomena [Chamaecladon Clade]}

\author{
Wong Sin Yeng ${ }^{1,2,3, *}$, Peter C. Boyce 3 , Alistair Hay 4,5 \\ ${ }^{1}$ Institute of Biodiversity and Environmental Conservation, Universiti Malaysia Sarawak \\ 94300 Kota Samarahan, Sarawak, Malaysia \\ ${ }^{2}$ Harvard University Herbaria, 22 Divinity Avenue, Cambridge, MA 02138, USA \\ ${ }^{3}$ Department Biologie I, Systematische Botanik und Mykologie, Ludwig-Maximilians- \\ Universität München, München, Germany \\ ${ }^{4}$ Royal Botanic Gardens, Mrs Macquaries Road, Sydney 2000, Australia \\ ${ }^{5}$ Jardín Botánico de la Paz y Flora, Bitaco, Vale del Cauca, Colombia. \\ ${ }^{*}$ Corresponding author. E-mail: sywong@unimas.my
}

\begin{abstract}
Two ornamental new species of Sumateran Homalomena [Chamaecladon] are described: Homalomena anthurioides S.Y.Wong, P.C.Boyce \& A.Hay and H. pexa S.Y.Wong, P.C.Boyce \& A.Hay. These novelties represent a continuation of discoveries on Sumatera of species with uniquely, for Asia, highly elaborated epidermis.
\end{abstract}

Keywords: Araceae, Homalomena, Chamaecladon, Indonesia, Sumatera.

\section{INTRODUCTION}

The existence on Sumatera of Homalomena Schott [Chamaecladon Clade] with extraordinarily ornamented leaf blades and/or petioles has been known since at least the 1920s, Alderwerelt (1922) having described three species with ornamented leaves: $H$. asperiifolia Alderw., H. cristata Alderw., and $H$. doctersii Alderw. The past decade has witnessed a marked increase in discovery of such species, among which are some of the most astonishing aroids yet described from the Malay Archipelago.

Previous papers in this series have described six such species (Boyce and Wong 2012; 2013; 2016a,b,c). Here we describe a further two novelties; one with the entire plant densely covered in scale-like hairs, and with the newly emerging leaves and exterior of the spathe with a dense fleece of soft shaggy trichomes, and the other with remarkably stiff and brittle microscopically asperous leaf blades, and petioles with a pronounced proportionately very large apical geniculum.

Both species described here are highly ornamental and have already attracted the attention of horticulturists. For this reason, we are withholding precise information about the type localities. 
1. Homalomena anthurioides S.Y.Wong, P.C.Boyce \& A.Hay, sp. nov.

Type: Indonesia, Sumatera Utara, South Tapanuli, precise locality withheld for conservation purposes, Keisuke Hase LA0818-02 (holotype ANDALAS!; isotype SAR!). (Figure 1).

\section{Diagnosis}

Homalomena anthurioides is immediately distinguishable from all other described species by the very narrowly elliptic to falcate, stiff and brittle leaf blades held deflexed to almost $90^{\circ}$ to the petioles, blades abaxially with alate primary lateral veins, and petioles with a pronounced apical geniculum (ca. 1/5 the length of the petiole). From all other Homalomena [Chamaecladon Clade] species $H$. anthurioides is unique these characteristics, and additionally by the spathe pure white at anthesis. From all Homalomena with a geniculum terminal on the petiole $H$. anthurioides differs by an unconstricted spathe and pistils with an associated staminode (vs spathe with a constriction concomitant with the top of the pistillate zone and pistils with no associated staminode).

\section{Description}

Lithophytic tufted pendulous-leaved herb to ca $15 \mathrm{~cm}$. Stem condensed, in larger plants erect, to $\mathrm{ca} 5 \mathrm{~cm}$, ca 1 $\mathrm{cm}$ diam., shoots pleionanthic; internodes obscured by overlapping leaf bases,. Leaves many together (up to ca 18 per stem); petiole slender, dorsally very narrowly canaliculate, $2-4.5 \mathrm{~cm}$ long, ca $1.5 \mathrm{~mm}$ diam., about one third the length of blade, sheathing in lower $1 / 5$, with a prominent terminal geniculum ca. $1.5 \mathrm{~mm}$ wide, straight or somewhat sigmoid, very minutely asperous, pale greygreen to dull brown-maroon; petiolar sheath fully adnate to petiole, wings triangular, c. $2 \mathrm{~cm}$ long, $4 \mathrm{~mm}$ wide at base, spread flat, margins somewhat hyaline, greenish to dull brown-maroon; blade deflexed at $\mathrm{ca} 90^{\circ}$ to the petiole, narrowly elliptic-lanceolate, often somewhat falcate, stiffly-leathery and brittle, $6-13 \mathrm{~cm}$ long $\times 2.5-5 \mathrm{~cm}$ wide, emerging pale pinkish maroon, maturing to rather pale grey-green, all surfaces very minutely asperous, base broadly cuneate, tip long-acuminate and apiculate for $\mathrm{ca}$ $3 \mathrm{~mm}$, midrib slightly impressed adaxially, prominently raised abaxially; primary lateral veins in 3 pairs, diverging at ca $30^{\circ}$ from midrib, each pair running into the faint marginal collective vein, slightly impressed adaxially, conspicuously hyaline alate abaxially; interprimaries extremely fine; secondary veins arising from midrib, very fine and not at all alate; tertiary veins forming a faint tessellate reticulum. Blooms up to 3 together opening sequentially in a synflorescence, with a faint resinous odour at anthesis, peduncle semi-erect at anthesis, later declinate; peduncle slender, ca $3 \mathrm{~cm}$ long, $1 \mathrm{~mm}$ diam., glossy maroon. Spathe ca $1 \mathrm{~cm}$ long, ca $5 \mathrm{~mm}$ wide across base, oblong, not constricted, pure white, interior glossy white, apex blunt with a terminal mucro to 0.5 $\mathrm{mm}$ long, spathe inflating at anthesis and opening by a very narrow longitudinal slit, later closing and enclosing spadix. Spadix ca $9 \mathrm{~mm}$ long $\times 3 \mathrm{~mm}$ diam., fertile to tip, sessile; pistillate floret zone ca $2.5 \mathrm{~mm}$ long; pistils few, in two or three whorls, cylindric-globose, ca $1 \mathrm{~mm}$ tall $\times$ 0.7-0.8 mm diam., dirty greenish, stylar region slightly tinged yellowish; stigma sessile, $0.2-0.3 \mathrm{~mm}$ diam., producing a large droplet at anthesis; pistillate florets mostly each including one staminode, this ovoid, sessile, ca 0.3 $\mathrm{mm}$ diam., waxy white; suprapistillar interstice absent; staminate flower zone ca $6 \mathrm{~mm}$ long, stout-conic, apex blunt; stamens densely arranged with groups of 2-3 vaguely arranged into discrete florets, thecae somewhat elongated-globose, ca $0.3 \mathrm{~mm}$ long $\times$ ca $0.4 \mathrm{~mm}$ wide, white, terminal part somewhat translucent, thecae opening by a wide terminal slit; pollen powdery. Fruiting spathe declinate by deflexing of basal portion of peduncle, remaining white. Fruits and seeds not observed.

\section{Etymology}

The epithet is formed from Anthurium, a genus of Neotropical aroids, and -oides - resembling - alluding to the general resemblance of the new species to a miniature pendent-leaved Anthurium, in particular the manner in which the petioles have a distinct terminal geniculum, a feature typical of Anthurium but very uncommon in Homalomena, where in almost all species there is an obscure geniculum about half way to two thirds of the way along the petiole, but very seldom at the tip.

\section{Distribution}

Known only from the type locality.

\section{Ecology}

Lithophytic on shaded moist banks of fractured metamorphic sandstone above the flood zone of forest streams in humid lowland gallery forest; ca $120 \mathrm{~m}$ asl.

Notes

All described Homalomena species have a geniculum present on the petiole, in the overwhelming majority of species positioned between half way and two thirds along the petiole, and usually discernible only as a distorted segment of petiole. A very few Bornean species, Homalomena geniculata M.Hotta, $H$. pseudogeniculata P.C.Boyce \& S.Y.Wong, and H. punctulata Engl., are 


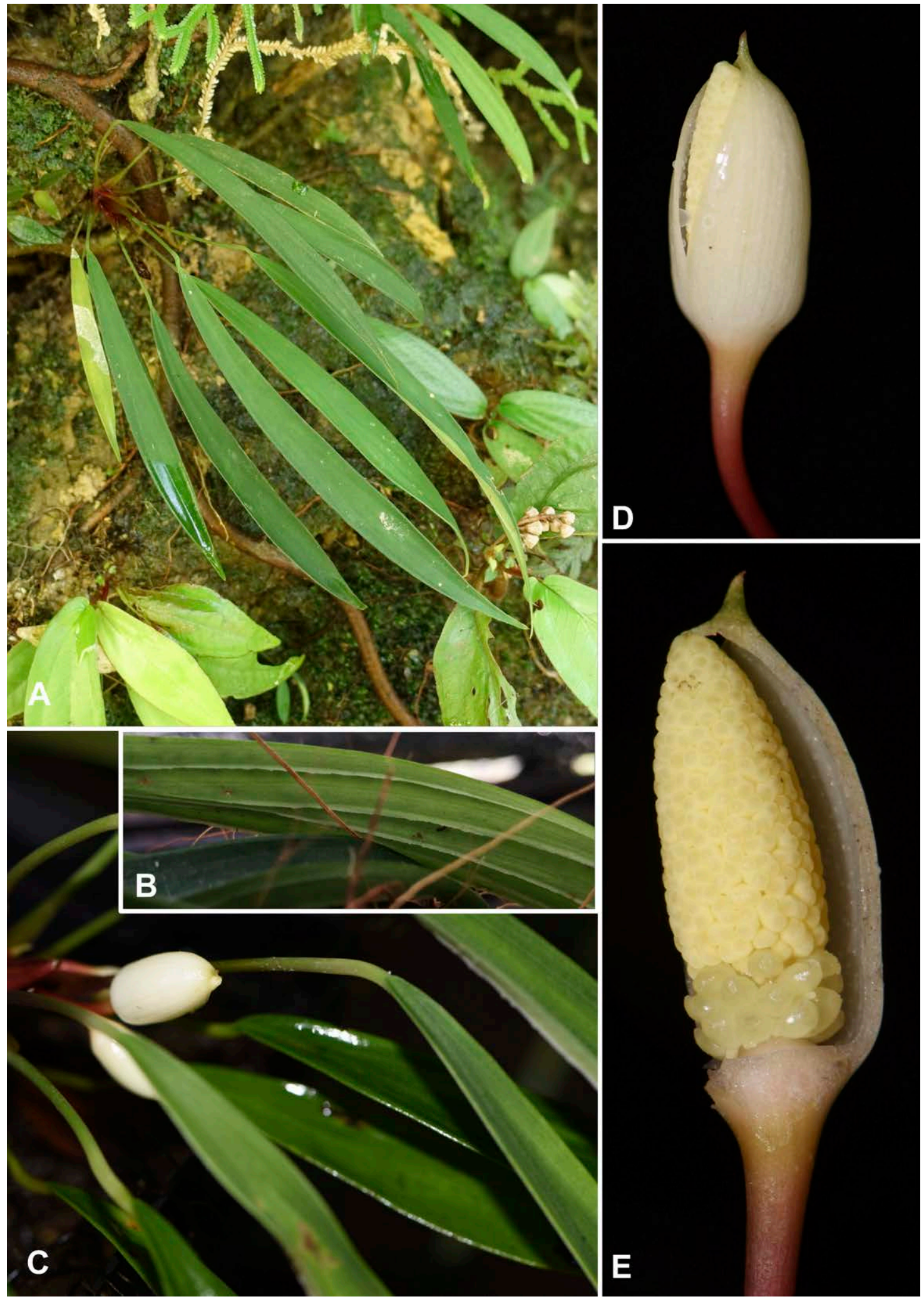

Figure 1. Homalomena anthurioides (A) Plant in habitat. (B) Detail of the alate primary lateral veins on the leaf blade abaxial surface. (C) Detail of flowering plant, bloom at late staminate anthesis; (D) Bloom at late pistillate anthesis. (E) Bloom at late pistillate anthesis, nearside spathe artificially removed. All from LA0818-02. 
remarkable for having the geniculum at the tip of the petiole its junction with the leaf blade, although even in these examples the geniculum is rather obscure.

\section{Homalomena pexa S.Y.Wong, P.C.Boyce \& A.Hay, sp. nov.}

Type: Indonesia, Sumatera Utara, South Tapanuli, precise locality withheld for conservation purposes, Keisuke Hase LA0818-01 (holotype ANDALAS!; isotype SAR!). (Figure 2).

\section{Diagnosis}

Homalomena pexa differs from all other Homalomena by combination the entire plant being covered with dense trichomes, with those of the petioles, newly emerging leaves, and spathe exterior forming dense soft shaggy fleece, and the cordate leaf blades. The nearest species in terms of indumentum is Homalomena hasei which differs by the much less dense covering of trichomes, the narrowly oblanceolate-elliptic blades abaxially glabrous, and spathe limb glabrous externally.

\section{Description}

Lithophytic, occasionally terrestrial rosette-forming herb to ca $7 \mathrm{~cm}$ tall and $20 \mathrm{~cm}$ across. Stem condensed, ca 3 $\mathrm{cm}$, ca $1.5 \mathrm{~cm}$ diam., reddish, shoots pleionanthic; internodes obscured by overlapping leaf bases, not conspicuous. Leaves several together (up to ca 9 per stem); petiole stoutly sub-terete, dorsally somewhat flattened, 7-12 $\mathrm{cm}$ long, ca $5 \mathrm{~mm}$ diam., ca $1 / 2$ to about equalling the length of the blade, sheathing in lower $1 / 5$, densely white tomentose with coarse multicellular scale-like hairs; petiolar sheath adnate to petiole, $2-2.5 \mathrm{~cm}$ long, wings triangular incurved, dull red; blade oblong- to ovatecordiform, softy leathery, almost subsucculent, 8-18 $\mathrm{cm}$ long $\times 10-13 \mathrm{~cm}$ wide, emerging dull red with very dense tangled scale-like hairs, maturing adaxially rich medium green and densely dirty white tomentose with coarse multicellular scale-like hairs, abaxially green to brownish green, more sparsely hairy, base rounded, posterior lobes blunt, sinus rather narrow, tip acute and apiculate for ca $1 \mathrm{~mm}$, margins rather markedly recurved; midrib impressed adaxially, prominently raised abaxially, tomentose, tinged reddish; primary lateral veins ca 10 on each side diverging at ca $45^{\circ}$ from midrib, slightly impressed adaxially, raised, tomentose, and reddish abaxially; interprimaries much finer and more or less alternating with primaries; secondary veins arising from mid-rib and from larger primaries, tomentose; tertiary veins a very faint tessellate reticulum. Blooms up to 9 together in a simple (i.e., one sequence of blooms) synflorescence, without detectable odour, opening sequentially; peduncle semi-erect at anthesis, later declinate, rather stout, ca $4 \mathrm{~cm}$ long, $1.6 \mathrm{~mm}$ diam., inserted basally (i.e., not obliquely inserted) on spathe, pale red, with dense, pale, recurved tomentum. Spathe ca $3 \mathrm{~cm}$ long, ca $1 \mathrm{~cm}$ wide across base, not constricted, walls conspicuously thickened, exterior dull red, densely shaggy pale tomentose except for naked portion of spathe overlapped by the outer margin in bud, interior shiny pale pink, apex blunt with a blunt terminal mucro to $1 \mathrm{~mm}$ long, spathe inflating at anthesis and opening by a rather wide slit, later closing and enclosing spadix. Spadix ca $2 \mathrm{~cm}$ long $\times 5 \mathrm{~mm}$ diam., fertile to tip, stipitate; stipe conical, base flaring, ca $1.5 \mathrm{~mm}$ long, $1 \mathrm{~mm}$ in diam., creamy pink; pistillate floret zone ca $8 \mathrm{~mm}$ long; pistillate florets in three whorls, each comprising a pistil and one staminode, this teardrop shaped with a slender base, ca 0.3 $\mathrm{mm}$ diam., waxy creamy white; pistils globose to narrowly flagon-shaped, ca $1 \mathrm{~mm}$ tall $\times 0.7-0.8 \mathrm{~mm}$ diam., creamy white; stigma very briefly elevated, $0.2-0.3 \mathrm{~mm}$ diam., producing a large droplet at anthesis; staminate florets zone ca $1 \mathrm{~cm}$ long, ellipsoid, apex blunt; staminate florets densely arranged, stamens scarcely organized into perceptible florets, thecae ellipsoid, ca $0.4 \mathrm{~mm}$ long $\times$ ca $0.3 \mathrm{~mm}$ wide, cream, terminal part somewhat translucent, thecae opening by a slit extending fully across the theca; pollen powdery. Fruiting spathe declinate. Fruits and seeds not observed.

\section{Etymology}

From pexus in the feminine, Latin for combed or carded, used relative to the dense indumentum that characterizes the species.

\section{Distribution}

Known only from the type locality.

\section{Ecology}

Lithophytic or occasionally terrestrial on shaded banks of fractured metamorphic sandstone above the flood zone of forest streams in lowland humid gallery forest; ca $120 \mathrm{~m}$ asl.

\section{Notes}

The multicellular scaly indumentum of Homalomena pexa bears a remarkable resemblance to that of various (very much more robust) neotropical Philodendron species, notable among them the well-known $P$. squamiferum Poepp. (Guyanas, N. Brazil), P. squamicaule Croat \& Grayum (Costa Rica to Ecuador; Figure 

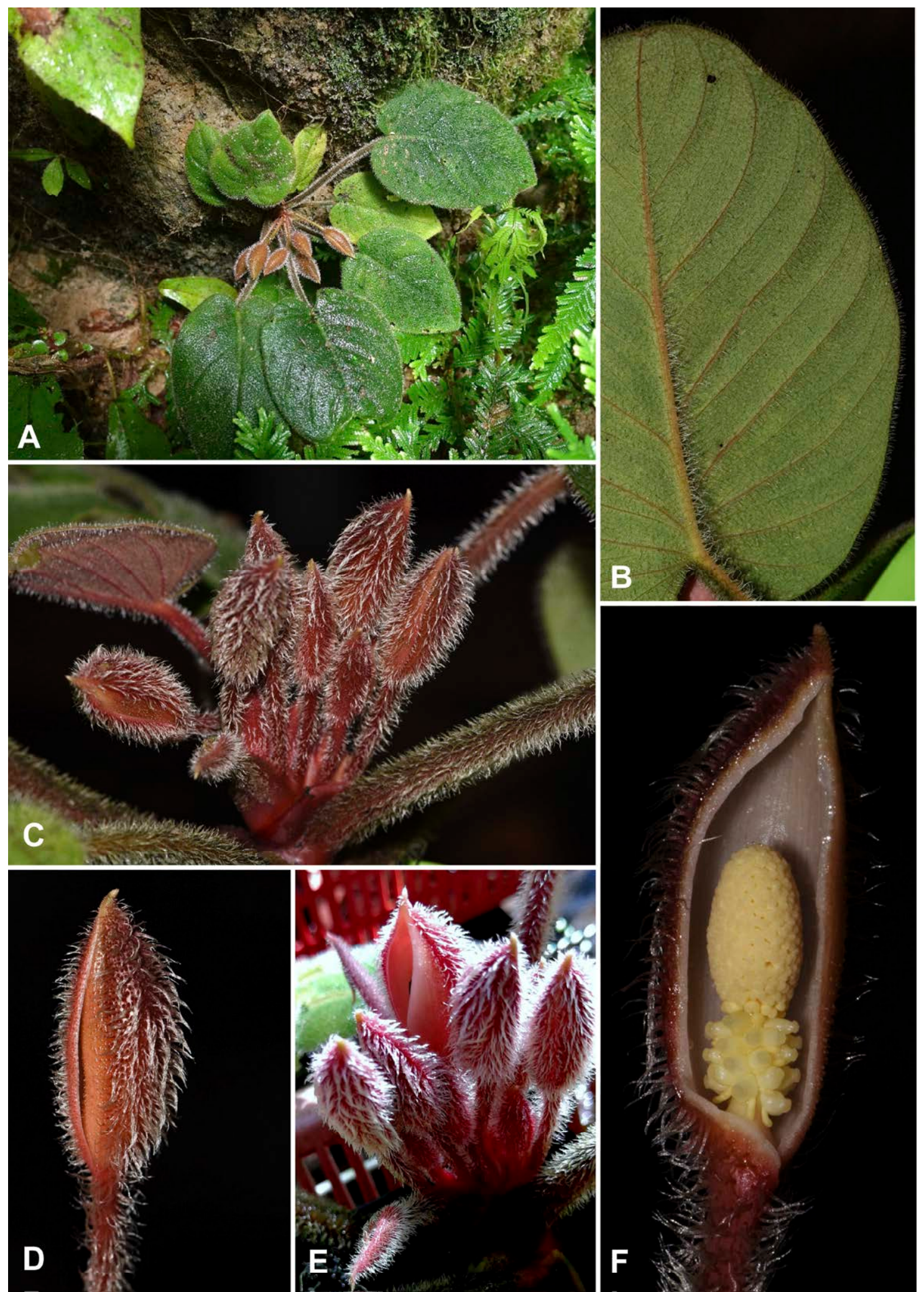

Figure 2. Homalomena pexa (A) Plant in habitat. (B) Detail of leaf blade abaxial surface. (C) Detail of flowering plant, bloom at late staminate anthesis. (D) Bloom at early pistillate anthesis; note the glabrous band running along the inner margin of the spathe. (E) Synflorescence with one bloom at staminate anthesis (F) Bloom at pistillate anthesis, nearside spathe artificially removed. All from LA0818-01. 


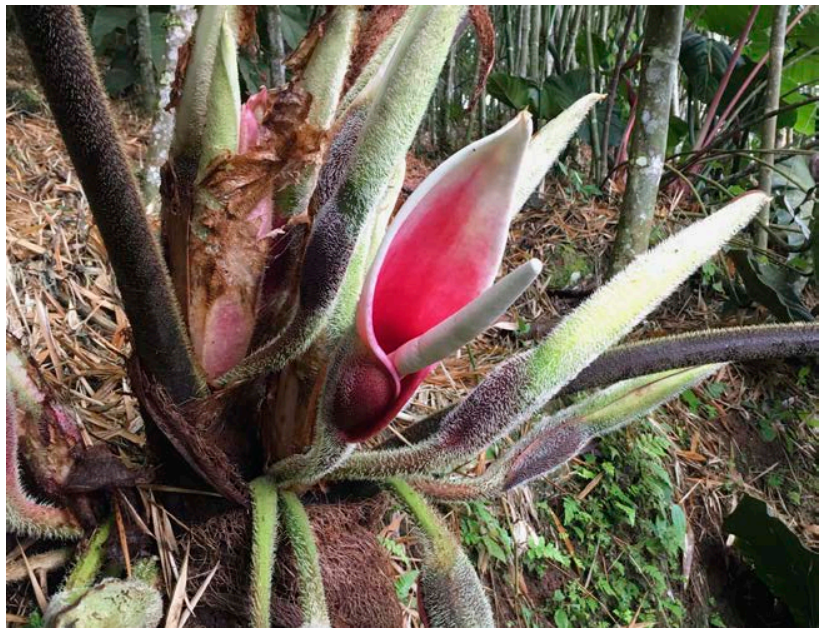

Figure 3. Philodendron cf. squamicaule, cultivated in the Jardín Botánico de la Paz y Flora, Bitaco, Colombia, showing a dense multicellular scaly indumentum on abaxial surfaces of the spathes and cataphylls, and on the petioles and peduncles. (Spathe about $30 \mathrm{~cm}$ long). Photo A. Hay.

3), and P. verrucosum L.Mathieu ex Schott (Costa Rica to Perú), though in these cases not extending onto the leaf blades but nevertheless similarly present on the spathes, peduncles and petioles. Molecular analyses have now well corroborated a close relationship between Philodendron and Homalomena (e.g. Cusimano et al., 2011; Wong et al., 2013, 2016), in turn suggesting that the presence of such distinctive indumentum in these two genera of the Philodendreae may not be wholly coincidental. Multicellular scaly indumentum is also known in some Bornean species of the less closely allied Schismatoglottis (Schismatoglottideae), e.g., S. ciliata A.Hay, S. crinitissima A.Hay, S. ferruginea Engl. and others, but rarely with such multicellular hairs on the blooms (Hay and Yuzammi, 2000).

Homalomena pexa and $H$. anthurioides occur at the same locality, the former favouring damper situations where there is a build-up of soil.

\section{ACKNOWLEDGEMENTS}

The collaboration and support of the Sarawak Forestry Department and the Sarawak Biodiversity Centre are gratefully acknowledged. The second author extends his thanks to Tan Sri Datuk Amar Leonard Linggi Anak Jugah and Malesiana Tropicals Sdn Bhd for continued support and encouragement. We thank Nils Köster (B) for the identification of the Philodendron in Figure 3.

\section{REFERENCES}

Alderwerelt Van Rosenburgh CRWK. 1922. New or noteworthy Malayan Araceae II. Bulletin du Jardin botanique de Buitenzorg ser. 3, 4: 163-229.

Boyce PC \& Wong SY. 2012. Studies on Homalomeneae (Araceae) of Sumatera I: Homalomena hypsiantha, a distinctive new species of the Chamaecladon Supergroup. Webbia 67(2): 147-150.

Boyce PC \& Wong SY. 2013. Studies on Homalomeneae (Araceae) of Sumatera II: Homalomena limnogena, a novel species from Pulau Belitung, and the first record of colonial helophytism in the Homalomena Chamaecladon Supergroup. Webbia 68(2): 77-79.

Boyce PC \& Wong SY. 2016a. Studies on Homalomeneae (Araceae) of Sumatera IV: Three new species of ornamental Homalomena [Chamaecladon clade]. Willdenowia 46(2): 253-260.

Boyce PC \& Wong SY. 2016b. Studies on Homalomeneae (Araceae) of Sumatera V - Homalomena squamisdraconis, a new species for the Chamaecladon Clade. Aroideana 39(2): 121-125.

Cusimano N, Bogner J, Mayo SJ, Boyce,PC, Wong SY, Hesse M, Hetterscheid WLA, Keating RC \& French JC. 2011. Relationships within the Araceae: comparisons of morphological patterns with molecular phylogenies. American Journal of Botany 98: 654-668.

Hay A \& Yuzammi. 2000. Schismatoglottideae in Malesia I - Schismatoglottis. Telopea 9: 1-177.

Wong SY, Tan PJ, Ng, KK, Othman, AS, Lee HB, Ahmad FB \& Boyce PC. 2013. Phylogeny of Asian Homalomena (Araceae) based on the ITS region combined with morphological and chemical data. Systematic Botany 38: 589-599.

Wong SY, Meerow AW \& Croat TB. 2016. Resurrection and new species of the neotropical genus Adelonema (Araceae: Philodendron Clade). Systematic Botany 41: 32-48. 